\title{
THE ANATOMICAL STUDIES ON THE LARYNGEAL MUSCLES OF THE JAPANESE
}

\author{
By \\ T. MANJOME \\ From the Oto-Rhino.Laryngological Clinic, Branch Hospital, University of \\ Tokyo (Director: Assistant Professor Koichiro Oishi)
}

Intrinsic laryngeal muscles of fourteen cases were dissected under the binocular microscope to observe their disposition and arrangement. Serial microscopic sections of another five cases were made to compare with the findings obtained by above-mentioned method.

The results were as follows:-

1. The thyro-membranous and the thyro-epiglottic muscles cross the minor ary-membranous and the minor ary-epiglottic muscles at the dorso-lateral part of the laryngeal ventricle, or on the front of the triangular fovea of the arytenoid cartilage.

As these four muscles intertwine one another at the intersecting point, the directions of these muscle action are changed so as to expand the quadrangular membrane and the wall of the laryngeal ventricle. Accordingly, the laryngeal vestibule and ventricle are dilatated.

2. The vocal muscle is divided into two portions: the thyro-vocal and thyro-oblongatic portions. The former arises from the caudal part of the thyroid cartilage, runs dorso-cranially and reaches the vocal process, while the latter arises the middle part of the thyroid cartilage; runs dorsocaudally and reaches the fover oblongata. These two portions intertwine with each other. This characteristic structure is found distinctly at the dorsal third of the vocal muscle. These muscle portions are not inserted to the vocal ligament.

However, in four cases among fourteen on dissection, another muscle bundles, i. e., the aryligamental portion is found inserting to the dorsal third of the vocal ligament. It is considerably difficult to divide the ending of muscle fibers on serial sections.

3. Thyro-vocal muscle which Goerttler stated in his paper that it arose from the thyroid cartilage and reached the vocal ligament was unable to be recognized.

4. Muscle bundles close to the vocal ligament are more slender than those of the lateral part, .and they are intermingled with elastic fibers, running parallel with them.

5. Muscle bundles inserted to the elastic cone are observed, but their quantity shows the individual difference and in some cases these bundles are not observable.

6. The structures of the lateral crico-arytenoid, the posterior crico-arytenoid, the arytenoid and the crico-thyroid muscles are observed and their functions are considered.

7. The submucous connective tissue of the vocal and the ventricular ligaments is dense, but the other part loose. The collagene fibers are intermingled firmly with the muscle and elastic fibers, taking part in the morphological change of the wall of the laryngeal cavity.

8. As far as dispositions of the laryngeal muscles are concerned, the several months old foetus and the adult show no essential differences. 


\title{
日本人の喉頭筋に関する解剖学的研究
}

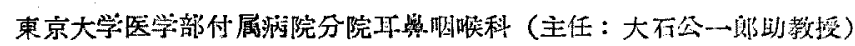

$$
\text { 万城目忠充 }
$$

目次

\section{I 緹 言 \\ 1敨部の洘察 \\ 【方法わよび材料 \\ N 実験成籍}
A）成人例にっいて
B）眙兒例につけて
C) 粘膜下結合組織について

\begin{tabular}{ccc}
$V$ & \multicolumn{2}{c}{ 総括まよび考按 } \\
V1 & 結 & 言 \\
& 交 & 献 \\
& 附 & 図
\end{tabular}

\section{I. 粕 言}

発声特，呼吸時における喉融内腔の動きは，喉頭鏡の 発明 (Garia, M. 1854) 以来, 容易に観察されるよ5に なつた・更にストロボスュープの応用（Oertel，1878., Réthi, 1896., Musehold, 1898.)1), 映画撮影 (Farnsworth, 1940., Pressman, 1942., 2) 端田, 19393)，切替， 19434)，立木 1958.5ａ）により，声帯は単なる 水平運 動ではなく上下にも動く，すなわち棈円運動をしてい ることがわかつた：近年は，テレビジョンの店用によつ て，一畤に多数の観察む可能となつている（立木 1956., 5) b).

この声帯運動については，二つの説がある・

I) Myoelastic Theory or Tonic Theory

声带唇は筋の作用により左右相寄ると，これが呼気生 により押し開かれる・また，声帯唇が弾性で相寄り声閒 を閉す，呼気圧で開く.こうして声門において空気の䠅 密波ができ，更にこれが附属管胵，咽頭，勫腔等を経 て，音声となるのである.その振動数は，気生の力と気 印の容積平均之, 更に声带唇の張力により決定されると い.

I) Neuro-muscular Theory or Clonic Theory

Husson, R (1950)6)は，ストロボスニープによる観 察, および動物や人間に括ける声帯唇の筋電図上より本 説を提唱した。
声带唇に含まれる笳束は，大脳細胞よりのりズミカル な刺激をらけて収縮し，その刺激伝遒と筋収紨との関係 は，各振動数によって異なり，500cps 上下では Monophasis, 500 1000cps では Biphasis, 1000〜1500cps で は Triphasis, 更に特別には $1500 \mathrm{cps}$ 以上で Quadriphasis の場合むあるという・

Portmann ワは両説に対する批判の中で後説について は䐅頭を単なる筋性の器官としてぶなく，神経と筇を結 びつけた生理を考えるところに意義があるとし，音声障

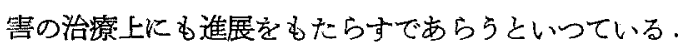
しかし，本説には筋電図学上よりの批判るあって，直ら に肯定されない現状である。

さて, 以上の生理学的, 臨床的観察の基礎である喉頭 の解剖学的研究は甚だ多いがこれを筋の走向，配列に限 つてる，その詳細に至つては，な蟥なるところがある。

私は声帶筋, 仮声帯筋を含めて侯頭内壁に直接する各 笳の構築像を検討し，知見を得たので報告する・

\section{II. 文献の考察}

1) 声帯の名称について

いわゆる声率に関する名称は，諸家によつて，多少異 なつているので注意しなければならない.

Schumacher ${ }^{8)}$ は, 喉頭内膘に突出したプリズム状の 部分を Labium vocale, Stimmlippe (声带櫭, vocal fold)とした. Stimmband (声帯, vocal cord) とは Elartisches Band 孛い5. Sieglbauer") で前頭断面が三角形を示す粘膜の裝を Stimmfalte，を たは，Stimmlippe とし，臨床家が真声带といら部位で あるとい5. Rauber ${ }^{10)}$ は，三局プリズムの形をとる 全体を Labium vocale とい〉，その自由緑を Plica vocalis, Stimmfalteあるいは Stimmband とする・

Katzenstein ${ }^{11}$ は， M. thyreo-aryt. int. を含を三 稯のプリズム状の部を Stimmlippe と定載している. Ertze 1:)は，弾性円錐の上緑で愿くなつている部を， Lig. vocalis, wahres Stimmband とい5. 前頭断で三 角形を示し，内に筋肉を含主部分を，Stimmlippe また は Labium vocale という. 声帯唇の辺縁を, Plica vocalis,あるいは Stimmfalte と定議している。 
Fränkel 13) は; 声帯縁の上方 1.8〜2.5mm, 下方 1〜 1,5mm の籍囲では，粘膜下に腺組織を誌めないしか し, Mayet 14) は, 腺組織の有無中，扇平上皮の箸囲で， 声带と弾性円錐の区別をすることはむつかしいといつて いる.

2）声帯筋について

甲状披裂笳のうち，声带唇に含まれる筋束は，いわけ る声帯㳙 (Zuckerkandl) といわれ，甲状軟骨と披裂軟 骨を結んでいるが，その筇構築像は，なかなか複雑であ る・旧くより論せららているのは, 筋束と声帯靱帯の関 係である (表1).

Lauthe (1835) 15) が，靶帯へ附着する笳束を誌め てから, Henle (1839) 16), Ludwig (1858) (Portio ary-vocalis),17) Rancallo (1939) が，これに賛成した・ Jacobson (1887) 18) は，20䐅頭中，3例にPortio. aryvocalis を諗めず，Merkel, Fr. (1895) も筋束の附青 はあるあのと，ないるのがあるといらたが，更に，全 く附着を諗めない者は, Harles (1853), Luscka (1862) 19), Verson (1868) 20), Némai (1937) 21) らである。

1950年 Goerttler 22) が，この問題を精細に検索し， 声深勒带に附着する筋束を認め，いわゆる Vocalis System を提唱していらい, Pernkopf 23), Trendelenburg 21）与子，これを引用し，Husson む；支の説の基礎に 採用して，こ」に本筋の構築像は，再び活潑に論ぜられ るようになつたのである。

Wustrow (1952) 25) は, Portio thyreo-vocalis と Portio thyreo-muscularis にわけ, 雨者は内転時のみ 交叉し，外転時には平行になる。革界帯に附着する䈤束は
殆どないが，検索例 22 䐅頭中，2 例に披裂軟骨と声带 勒带を結ふ筋束を認め，これを，Portio ary-ligamentosa としているが，要するに，Goerttler の意見に㤆 対している。

Mayet (1954), J,v.d. Berg u. Moll (1958)เ6), Shl.

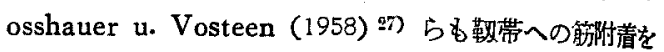
認めない. Behringer (1954) 98) は，筇束の大半が声带 䩓带および弾性円錐に附着し，䈌束は内転時，外転洔を 問わす靱帯に斜めの力向をとるとい〉，Goerttler を支 持している.

本邦では，喉頍等全般について，二本杉 (1923) ${ }^{29}$ が，

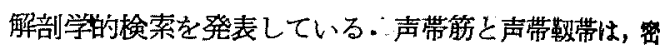
接しているが，附着いかんは；な和不明であると迷べ た.

Kano, S (1910) ${ }^{30)}$ は Erlangen に和いて発表して いるが，声帯突起におこり声帯䩒帯に附着する極く少数 の筇束がある・これは，声帯唇の繁張を調整し，筋が正 中に向い膨隆するのをふせぎ, また, 声带突起が声門に 突出しないように作用するものであるといつている。

以後，あまり問題にされなかつたよらである・戦後た なつて，小西，小山 (1953) 31 5の組織学的研究が灰 られるが，筋線維の断面の形状，太さなどを問題とし， 筋配列の点には言及していない。

大石 (1956) 32) は, 一声楽家の䐅頭について精細に

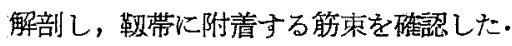

広戸，伊藤 $(1958)^{33)}$ は，組織学的に，声带鞓帯に筋 束の附着を認め，靶帯に平行な筇束はないとして，Goerttler の説に賛成している.

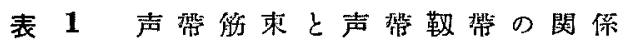

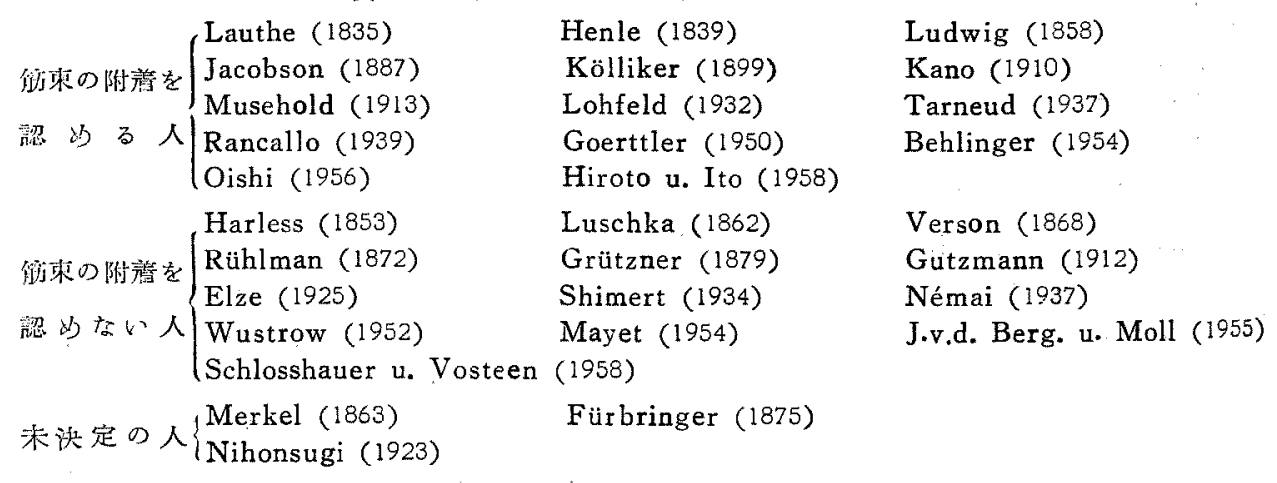

III. 万法および材料

筋荣の走向，配列を检索する方法は，大別して二つあ る・一つは連続切片によるるのである・これは笳線維と
周围の関係を容易に知り得るが，筇束の走向を满定する 上には，数多い切片を観察する労があり，亲た，誤り易 い. 他の方法は，挺大鏡下に，筋束の一本一本を分け 
て，その起始より附着まで追求するのである・これも抆 獄上の熟練を要するが，笳束の走向を把握するには前者 より容易である・私性主として後者の方法をとり, 前者 恃補助的に用いた。

双眼拡大镜 $(\times 6 \sim \times 40)$ 下に，極小解部用攝子，同 錸および絧針に割箬の柄をつけ針の尖端を種々に研い だものなどを，铔細部位の分離解剖に使用した。

標本は水醋酸を商下したり，ワンギーソン液の滴下に よる染色を行ないながら，水槽中で解剖した．著进処理 をしたものは，結合組織と笳束の分離が容易になる。

筋線維の末端は，必要沈して摄子で小さくとり，普 通顆敞鏡，あるいは位相差顕微鏡下 $(\times 100 \sim \times 200)$ に 礁かめた。

本材料は，東京都監察医務院之東京大学附属病院分院 病理倹查空より提供された正常と思われる喉頍である (表2および い).

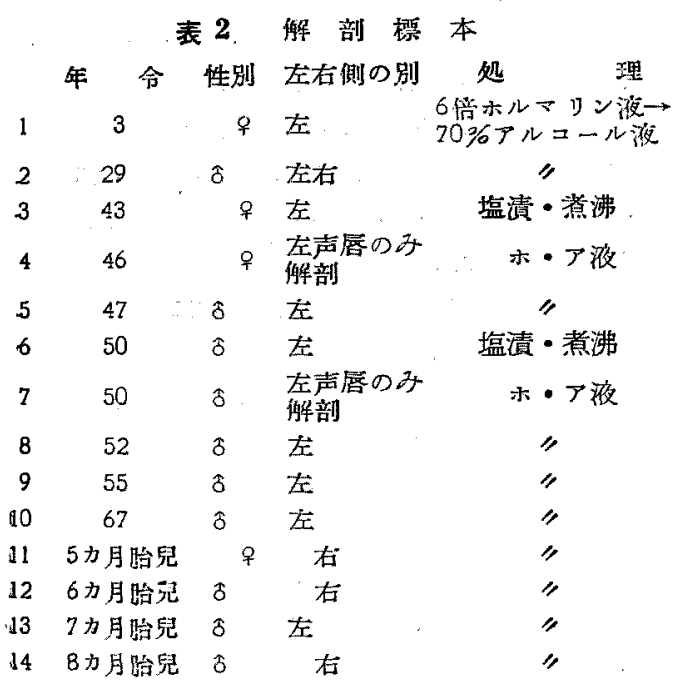

表 3 墥續切战標本

左右 声管人效

\begin{tabular}{|c|c|c|c|c|}
\hline 年令 & 性别 & 钢口 & 方回 & 染 \\
\hline 30 & q. & 它 & 水平断 & $\begin{array}{l}\text { エラスチカ・ワンギ } \\
\text { ーリン }\end{array}$ \\
\hline 47 & $\delta$ & 右 & 水平断 & " \\
\hline $\begin{array}{l}\text { 5力月 } \\
\text { 胎 兒 }\end{array}$ & $q$ & 在 & 先状断 & $\begin{array}{l}\text { マトキシリン・エ } \\
\text { オジン改びエテズ } \\
\text { カ, ワンギーソン }\end{array}$ \\
\hline $\begin{array}{l}\text { 6力月 } \\
\text { 路兒 }\end{array}$ & $\hat{o}$ & 右 & 水平断 & $"$ \\
\hline $\begin{array}{l}\text { 8力月 } \\
\text { 咍兒 }\end{array}$ & $\hat{o}$ & 左 & $\begin{array}{l}\text { 舖後側一 } \\
\text { 約15度 }\end{array}$ & " \\
\hline
\end{tabular}

\section{IV. 実験成 精}

A) 成人例飞つい,

1）上甲状披裂筋 M. thyreo-arytenoideus superior (Santorini), M. thyreo-arytenoideus sup. lat. (Krause), M. thyreo-arytenoideus min. (Sommering) 甲状軟骨内角部の中央より上部で，軟骨膜におこり， ほら゙水平に甲状䑤骨板の内側を後方に走り，喉顽室外側 後部で，や小内方に下行し，披裂軟骨の的突起に附着す

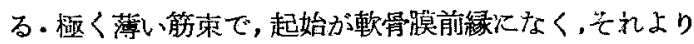
4〜5mm 後方の場合もある(29才，47才例第 1 図 a.). あるいは本筋束を全く欠く例もある( 43 才第 2 图 a，8

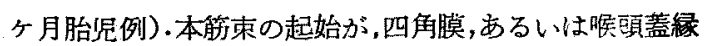
にあるもの（小披裂四角膜笳，小披裂煀頭蓋筋 M. aryepiglotticus minor or rectus, $M$. ary-membranosus minor or rectus 二本杉) む，多くみられる。その附

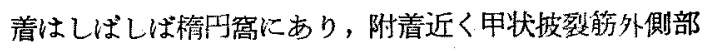
に被われる。

2) 甲状披裂筋外側部 M. thyreo-arytenoideus lateralis, M. thyreo-aryt. inf. ascend. (Fürbringer, Gegenbaur), Pars thyreo-aryt. inf, m. crico-aryt. (Möller), Stratum ext, cricothyreoarytenoidei (Merkel, C.L.)

a）表罢は斜的上方に走り，四角膜に附着する。 M. thyreo-aryt. med. (Santorini), M.thyreo-aryt. sup. (Tourtual) Stratum thyreo-aryt. inf. ext. (Fürbringer)

すなわち甲状軟骨内角下半部，あるいは甲状軟骨下 緑，時には下甲状結節の軟管膜に起り(47才例第 1 図a.)， 斜め後上方に走り，知頭室外側後部(披裂軟骨三角窝の前 方)で，上甲状披裂筋の内側を，それと，㴗心゙直角に交 り，更に，そのすぐ内側上部で，小披裂譺頭蓋筋あるい は小披裂四角膜筋々東と交叉した後，康状沉㹡散し，細 い筋束となって，あるいは前内下方に向い仮声帯勒帯に まぎれこみ，あるい性前内上方に向って四角膜粘膜下，

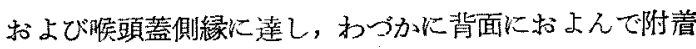
する・本筋束の上半部すな和ち仮声带部に入つてから は，その間に腺組織や脂肪組渽が多く，結合組織は眯で ある。

b) 们筧は M. thyreo-aryt. inf. (Santorini)

M. thyreo-aryt. inf. intermed. (Fürbringer) ל 四ばれる．声帯部の外側にある筋束で，甲状软骨内角 におこり，後方に走つてその大部分は，披裂軟骾楕円简 の大半，お゙よ゙筑突起の一部に附着し，一部分は棈円窩 
に附着せず披裂筋に移行する埸合も゙ある(第 1 図 a). 一般に筋束は比較的太く，それぞれ，ほづ平行に走り， 附着部位に近く，小披裂四角膜筋中小披裂啹頭蓋筋之交 叉する・

本筋外面の結合組織間には腺組織や小脂肪塊を認め， また，上甲状動静脈の分枝，反回神経の分枝が筋束を縫 らように梁部へ侵入する。

c) 仮声帯筋 M. ventricularis, Taschenbandmuskel (Ruedinger) M. thyreo-arytaenoideus sup. medialis (Krause)

仮声帯内を，甲状軟骨内角より披裂軟骨三角窝まで走 る筋束で，同靯带の外側倿し，あるいは，その結合組 織に混っている・本筋の後 $1 / 3$ に上後方から，甲状軟 骨，披裂軟骨におこる筋束が入つてきている。

3）甲状披裂筋声帯部 M. thyreo-arytenoideus vocalis (Merkel,F.) M. thyreoaryt. inf. internum (Fürbringer) M.vocalis (Zuckerkand)

外側部との区別は著明でないが，筋束は外側に比べ細 くなり，挌の拉の交叉するようになる・この走向による 区別は，そう容易でないが起始で，上部にある筋束は附 着部で下外側になり，起始で下部にある筋束は反刘火附 着部で上内側になる・すなわち走向により分類すると，

a）甲状声带突起部 (Pars thyreo-vocalis)

矢状面では声帯縁に刘し前下方上り後上方に向 5筋束 で，水平面より反れば，声帯縁に刘し，前外方上り後内 方に弧を画いて括り，声帯緣に対する角度は，これに近 つ゚くにしたがつて小となり遂には平行となる。

b）甲状棈円窩部 (Pars thyreo-oblongata)

矢状面で前上方より後下方に向与筋束で，水平面では 前内方上り後外方に，ゅるく弧を画いている。

これらの筋棘間の関係るみると，起始，附着でならら 筇束が，途中で角度を異にする能束をはさむ場合があ る・また起始で一つの筋束が扇状に分かれ附着を別にす るときと，その逆な場合をみる・したがつて甲状声帯突 起部，甲状棈円窝部に区別しても，各筋束は単なる交叉 ではなく，交織しているものである。この交織は，全長 の $1 / 3$ の声帯突起に近い部分に 甚しい (第 5 図). 声带 靭帯に接する部位になると，笳束は，い上い上筋線維数 本程度に細くなり，弾性線䊒に混って，これと平行に走 る・この間を膠原線維が波状を呈して筋束を包み，ある

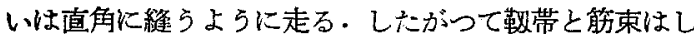
つかりついて括り，下方の弾性円錐と筋束との関釈のよ らではない。 c) 披裂靯带部 (Pars ary-ligamentosa)

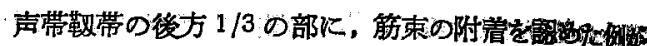

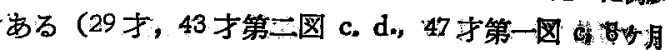

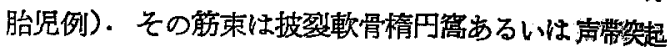
に連なる。

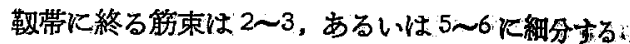
この分枝距離は短く䢧原線稚に連なって終つている。

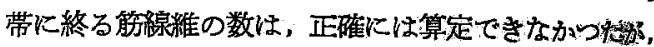
そう多いものではない.

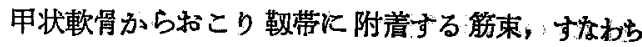
M. thyreo-vocalis (Goerttler) は確認するこを加で

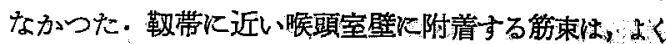
認められるが，これとは区別されなければならない。

弾性円錐と筋束の間は, 眯性結合組織で結ばれている か゚，弾性円錐にも附着する筋束がある。比較的太倗腺 なのが認められた例（47才第1図 b.c., 50才，55才例 之，比較的細い筋束て附着する例 (67 才例) と，また附 着を認めない例 (43 才例第 2 図 b. c. d.) があつた.

附着の場所は，側輪状披裂筇上縁近くのるの（47 才， 50 才， 55 才例）がある.このうち披裂軟骨と結心筋束の 場合は，側輪状披裂筇の弾性円錐に終る筋束，すなわち， M. syndesmo-aryt. (Fürbringer) と混同し易いか酒 者の間は，結合組織が 比較的厚くなつていて区別でき る・すなわち，この部の結合組織は常にあつく，筡束が 附着しない場合る，筋束を包むようになつて和り，弾性 円錐との䊅びつきは固いのである。

この汪か，披裂軟骨棈円窝に和こる筋束で，弹性円飭 の声帯突起近い部分に附着をみることがある(30才， 50 才例).

4）側輸状披裂筋 M. crico-arytenoideus lateralis, M.crico-aryt. (Meyer), M. crico-aryt. ext.u. int. (Tourtual)

輸状軟骨弓部上縁に括こり，斜め後上方に輪状㪀骨側 上面を被つて，披裂軟骨筋突起前部に至り，これ《附着 する.附着近く後輪状披裂筋々束に被われ，あるい恔 叉する.弾性円錐に拓こる筋束むある。これと，甲状披 裂筋の関係は前述した。

本施束間の相互関係は，特愎襍ではない，輪状唓骨 側後方の筋束方次第に短く，各筋束の方向は，能突起の 附着部位よりみると前方より斜め外方に開いて和り，输 状披裂関節面の長軸に対しては，内前方に向亏觔束か，」 外側方に向うすのよりる多い。

5) 輸状甲状筋 M. crico-arytenoideus, Pars 
recta et Pars obliqua, M-crico-thyreoid. (Zuckerkandl) $M$ cricothyreoid. anticus : Pars rect. $u$. Pars obliq (Fürbringer), M. crico-thyreoid. rect. u. obliq. (Luscka u. Henle), crico-thyroid muscle; ant or obliq. part and post. or horizont. part (Cunningham)

輸状軟骨外面の前㔚よび側方部におこり，中央部は上 方飞垂直に近く，側方部は水平に近く走り，甲状軟骨板

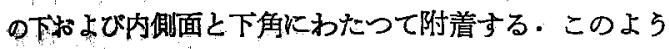
な筋束の走向により直部，斜部に大別されるが，その区

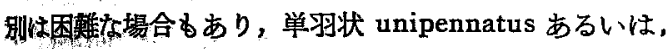
羽奖 bipennatusなど㮔くな組合せがあり，殊に斜部で 恃，表層上り内層で，上り水平近くなるなと゚，筋束の 走向を異にしている。

鉦部の下粶で輪状咽頭筋に接するか゚，その区別が必ず しも明暸てないい例がある。

本筋の变異については, M. thyreo-trach. profund., M. crico-trachealis, M. levator glandulae thyreoidae profund., M. thyreoid. trans. などがあるが，私の少 数例で観察されなかつた。

本筋の一部が，側輪状披裂筋に入る例があつつたが，後 輪状披裂筋との連絡は認めなかつた。

直部盛正中線で左右接している例はしばしばある，五 たそその觔束の一部が交又している例もあつた。

6）披裂筋 M. arytenoideus

a) 横披裂笳 M. aryt. transversus (P.N.A.), M. interaryt. trans. (Fürbringer), M. ary-arytaenoid. (Morgagni), M. aryt. proprius (Luschka)

両披裂軟骨側緑の下 $2 / 3$ を結ら横走の筇束で，各筇束 估䡫度の交叉，よぢれを呈するが，大体は平行である。 表層の觔束は一部俱論状披裂筋に連なる.甲状披裂筋之 る前述したように連なる場合がある・このような場合， 披裂軟骨側縁で耐筇束間が腱様のことが多い。

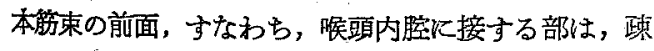
橉粘膜下結合組織で，筋束の附着をみない。

b) 斜披裂筋 M. aryt. obliquus (P.N.A.), M. interaryt. obliq. (Fürbringer), M. ary-epiglotticus (Luschka), Stratum ary-memb. (Merkel, C.L.), M. epiglottideo-aryt. (Hyrtl)

槽披烈筋の外層で，一側筋突起よりおこり斜上し，他

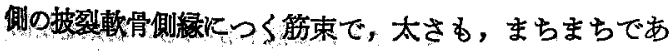
る・両側沉ある場合は，正中線で交叉するが，いずれが
背側になるかは，一定しない，一方が他方をはささむ例む ある・

斜披裂筋は，披裂堠頭蓋筋江連なる場合が多いてとの 間は腱様のときと，これを欠くときとがある。

斜披裂筋を久く例もある・年机は斜走の程度が少なく なり，ほとんど横走々，みなければならない程度まで， いろいろであるから，この間の区別がうきくいのであ る・

起始，附着の位置により，M. ary-corniculat. obliq., M. ary-corniculat. rect., M. crico-corniculat. などあ るが，自験例にはみなかつた。

斜披裂筋が側輪状披裂筋，甲状披裂筋外側部之連絡す る例がある・これるその間が腱様を呈する場合がある。

7）後輪状披裂筋 M. crico-aryt. post. (P.N.A.)

輪状軟骨板の正中線に近く，下部に向って広い面上り おこり，上側方に走り披裂軟骨筋觉起後部に附着する。 䶼束の走向は，上部で殆ど 水平に近く，中部は斜走し， 下部，側方部は殆ど垂直になつている・変異として， M. cerato-cricoid. (Merkel'sche Muskel) «一例 (55 才例に認めたが，M. cerato-aryt. は認めなかつた。

以上の各筋の变異，破格については，少数例で，論ず ることができないまた左右差についても今後の検索に ゆつ゚る。

B）胎児例について

本材料は，5 カ月以降のるので既に各筋はほ伍芫成し て和り，その走向も成人之特に買なってはいない。

声帯筋の走问も，すでに相当複䧴であるが，比輍的に は成人より交織の度合が少ない.声帯靶帯への附着も榆 索例によってちがっている。

声帯部の 分類す成人に括けるようにできると思われ る(第3図 b. c. d. e.).

眼につくことは，喉頭室の凹みが少なく，その下瀑 が、声帯勒帯より上部に，はなれていることである・す なわち，この部の粘膜下結合組織は比皎的厚い（第3図 b. 第4図 a).このことは，未だ㜊頭の㗢きが，始まっ てないからとみるべきであらう。

C) 粘膜下結合組織について

知頭内面の形態を变化させるのは，筋肉の収縮，弛緩 であるが，筇束と粘膜の間にある結合組織も問題にな る.この線維の走向は, 組織切片からもかかるが，簡単 なのは，粘膜裂㩐線を作ってみることである（第了図 a).

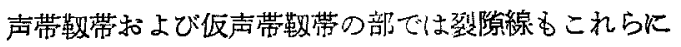


平行である、そして離れるにしたがつて，それぞれ直角 の方向に向っている・また声带突起下において，前後か らの線維功集うており，この部の結:合組織中，歷原線維

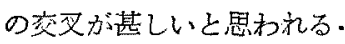

\section{V. 総括および考按}

㩔頭は，まづ気道の防賒器官として閉鎖的に㗢くこと は䒺統発生上から西明らかで，人では 1）披裂堠頭蓋ひ だ，2）仮声带，3）声鱼唇の三段でその作用を果して いる・発声器官としては声带唇の動きが重要であり, 更

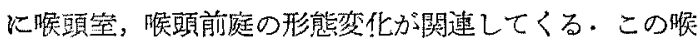

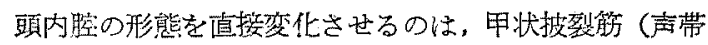

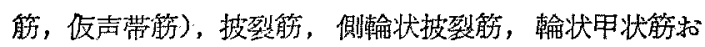
よび後輸状披裂筋である・輸状甲状筋を除いて他の筋は

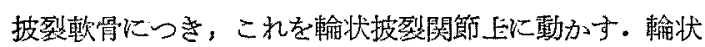
披裂関節は円柱状の面でその長軸は水西線汇対して前外 方に 45 度の傾斜を示している。

Stroud, M. H. \& Z wiefach, E. ${ }^{34)}$ ( 側毺状披裂筋 の作用を論じている・すなるら，側輸状披裂筋および後 睮状披裂筋の披裂軟骨へのつき方を観察し，前者は関節

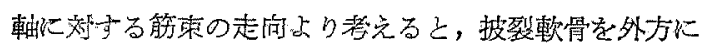
移動させるむのである.その内側の筋束のみ、これを内 前方に引く . 後者は関節長蟿几平行なのは側方の筋束の 一部で，大部はこの軸值角の方向をとつているから外 転の作用としては弱いむのである.披裂軟骨を後方にひ いて，披裂喉頭蓋ひだを緊張させるのである，それで側 輸状披裂筇は良来内転筇に分類されてきたが，外転筋で あり，後輪状披裂筋とは Synergist であるといつてい る・しかし，Capps ${ }^{25)}$ は，乙机否定し，側翰状披裂 筋は披裂瑱骨を内方に回転させ，外方炕は動かさないと いつている・すなわち屍体喉頭で，後能，側筋を同時に 引くと披裂軟骨は後上方に動き，声帯は幾分正中により

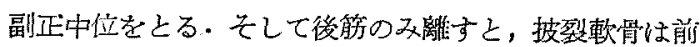
内方汇括ち，声帯色起は声門に入るようにみえるとい

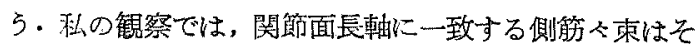
の外側の少数にすぎず，長さも短い。関節面長軸に対し 前内力に向万筋束の方が多いから側等の及学独に働くと 老光大場合は，披裂軟骨が関節の内側頂上に市るとき は，より外側に引くとしても，やはり内転睤としてよい と思う。

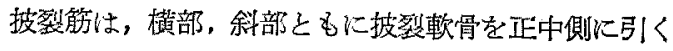
作用がある・その一部は喉頭蓋，孜るいは披裂呢頭蓋ひ

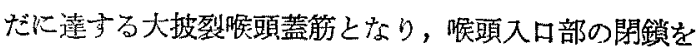
司どっている。
輸状甲状管は，輸状軟骨弓部前面之甲状軟胃下湜をつ ないでまり，翰状甲状関節を介して甲状軟骨下緑と铪状 軟骨弓部を近つけることにより，声帯の緊張を高めるる のである。

四角膜，喉頭蓋縁，仮声带，喉頭室壁拊着する筇束 は, 甲状披裂筇の外層に属する甲状四角膜筋, 甲状搌頭 蓋筋および上甲状披裂筋の変異とされている披裂四角膜

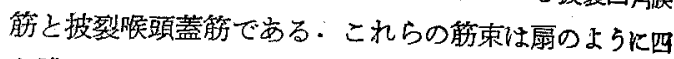
角膜に広がつている・そのがすにあたる部位は，堠頍 室の外側後部で披裂軟骨三角蓇の前方にあたる.この点

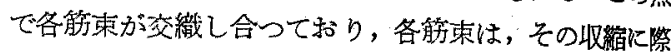
してこの部分で力の方向が変えられるのである・すなる ちこの部分は一つの作用点之考党られる・その際各箖束 間炕介在する腺組織や脂胋組織にる影響されると思 5 が，筇収縮はこの作用点の部位に向い，したがつて㬋頭

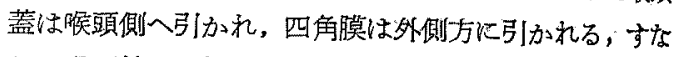
わ喉頭前庭は搪張されるわけである。

仮声带には前後に走るいかゆる仅声帯筋の活水，先 に逆べた作用点より过回して上方より仮声帯後 $1 / 3$ 亿入 る筫柬があるから，これは仮声帯をつり上げる作用があ るとみられる・だざし仮声帯筋同樣，先の量は個体差水

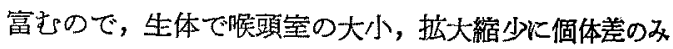
られるゆえんかとも考えられる・な特，喉頭室壁は外側

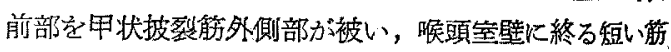
束が，その前後に認められるから、これらす室の变化炏

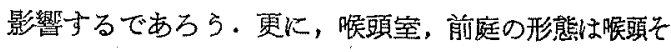
のもの〉位置移動，寸なわら前頸筋，甲状咽頭䈷によっ ても影響されるのである。

声带筋は，その起始附着の問题，声帯靯帯との関係， 筋束の分枝，叢状，交丑などの状態について，な打論争 が絶えない：この理由は検索方法の差にあると思われ る.

その方法は，刀刃剖查を可とする者 ${ }^{26)}$ と，組織刨片 よりする方法に砝実性を㴆す者 27) 28）とあるが，凨者 を併用している者が多い。

筋束の走向を追求するには細部を拡大観察する置 と，たんねえに解剖する接術で容易となるが，この刀为 剖査の難点をあげれば次の通りである.

1）短時間炕は，その手技に熟達できない，標本によ つて，もろさが翼なるので，笳束周围の結合組織を分け るのに余程の忍耐を要する・いつたん，筋束を甽断して しまうと，その連なりを忘れる恐れがある。筋束を切断 除去してしまえば，供覽することもできなくなる・これ 
を解浃するには頻繁に記録するよりほかにない、この記 绿には写真撮影がよいと思われるが，現状ではなお，ス ケッチに劣るようである。

2）標本に色彩の区版が少ないこと・これが写真撮影 では淽足できない一因ですあるが，同時に 解剖の難易 るこの点にある・私は，固定前の骠本で，カルミン滴 下,アントシアン染色，クロロフイル滴下などを試みた が，いずれ子満足起得才゙，ホリマリン，アルコール固定 後の標本で，組織染色に用いるェラスチカ，ワンギーソ ン牧を滴下することにより，や小満足を得た・滴下表面 はもちろん一様にフクシンの赤紅色をとるが，適宜，水 洗し，あるいはアルコール液に保存して色素がうすまる と、筋束はビ、クリン酸の黄色を呈し区別し易くなつた。

水醋酸を滴下し，䐪原線維を瞕化透明度を増す在来の 方法も併用した・募沸すると，結合組織が柔らかくなり 筋束を分離し易くなるが標本は綰少变形するから，募沸 時間などの点を考慮しなければならない。

3）䇷線維末端の区別が困難なこと・㹡大鏡の倍率 40 倍まででは，やはり筋線維終末を確かめにくいててれで 拡大鏡下に，こ〉と思われる部を極く小さく摄子でりま みとつて，載物ガラスにのせ，普通顕微鏡，あるいは位 相差影微鏡下 $(\times 100 〜 \times 200)$ に磁かるのである・そ の際, 切りとつた線維の方向をよく覚えて蛙かないと， 載物がラス上で走向が反対になつてしまら恐れがある。 このことは声帯鞄帯上の停止筋束が，前からきている か，後からかの決定に重要なのである。

次に連続划片の方法であるが，何といいても染色の自 由な点で優れている・諸家の染色は，Heidenhein 染色 22) 28)，固定前の Borax-Carmin 28)，をたは1\%クロー 么酸染色 28), Orcein 染色 ${ }^{14)}$ 28) および Bielschowsky 染色14)などである・私尼またエラスキカ，ワンギー ソン染色試み，箭線維，弾性線維，扣よび膠原線維の 区別を明らかにした。

Shlosshauer は切片を染色しないて，扁光影微鏡下 に筧繁している。

切片による場合，䈤束の走向決定のためには筋束の連 絡，附着を確実にし得ないこと，切片の数が大変多くな ることで容易ではない. Behringer. (120〜300 $)$, Shlosshauer, $(120 \sim 140 \mu)$ bは，切片を可能な限り愿くきり それを解決しようとしている・しかし，いかに厚くして る,あくまでる，これは切片であつて，笳束の連䅂，附 着を確定するには，非常に努力がいるのである・

各筋束の走向を一面に現わ文べく，Goerttler は声带
に水平な万向と斜方向の哪片を作つたが，それにしてる 的束の走向すぐてを現わすことはできない.乙かも一つ のブロックで各方向に切るかけにはいかないから、これ より個体差を判定することは不可能である。

いつれにしても筋湌索の方法に今後な山，解洪す心き 点があると思秃る。

声带胼を，その走向より二つに分けることには，賛成 している者が多い. Goertller は，M. thyreo-vocalis および M. ary-vocalis とい〉，いずれも声帯勒带に 附着する・その収維は丁度，タォルをしぼるような形 になる・すなから，声帯靶带に対する筋束はするいは Heberとしあるいは Senkerとして働らき，綜合的に は声門開大作用があるとしている．Wustrow は少数の 能束が声帯鞂帯に附萛する (Portio ary-ligamentosa) 例をみるが，一般には筋束は䩿带に平行に走る Portio thyreo-vocalis ¿ Portio thyreo-muscularis に分 け，雨者は，内転時方いは屋体位で交叉し，外転時心 は，平行であるという・また，声带靶帯には，附着しな いという.

Wustrow に賛成するのは Mayet, J.v.d. Berg, Moll, Schlosshauer, 於よび Vosteen らである.

私の所見では，声带靱带への附着筋束は少なく主とし

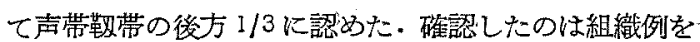
除いて 14 例中 4例である。乙かも，これらの符束は披 裂軟骨の棈円简，あるいは声帯突起に連なるもので，こ。 れは Ludwig のいう Portio ary-vocalis に暞当する. 亡思われる。

Jacobson 当本笳束を認めているが，欠く例もある之: いつている.

私は，甲状軟骨より声帯靱带につくとされている M. thyreo-vocalis (Goerttler) は礁認できなかつた，

したがつて・私は，声带胼を甲状声带突起部 (Pars thyreo-vocalis）之，甲状椿円窩部（Pars thyreo-oblongata）の二つに分け，分化の程度により，声帯鞓曼 に附着する筋束，披裂靶帯部 (Pars ary-ligamentosa)。 があると考えたい、

弾性円錐に附着する㳙束は，諸家の認めるところで， 私もしばしば垫めた・これる Behringer のいら「大半 が附着する」ほどのものではない，附着する笳束の太さ むいろいろである。

Schlosshauer は後方 $1 / 3$ の部に多いというが，必ら ずしもでらではない。

声帯筋々束相互の関保については，披裂敷骨の披裂関， 
節上の位置によつて 異なるとみなければならない。 Wustrow はこの点を指摘し，こ礼が諸家の異論の原因 であるという.

Némai も屍体位にある声带唇の形態を一定にして検 荣すべきであるとし，固定に先立つて結禁により前筋の 収縮を高めて，声帯を伸長させている・このことは特に 組織切片にする時は注意すべきであらう.刀刃剖查によ る時は，披裂軟骨の位置を動かしてみたり，外側，ある いは内側より観察できるから筋束相互の関係を容易に知 ることができる。

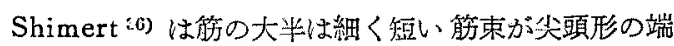
を結合組織でつぎつぎに連なり，それぞれ叢状を呈し ているので筋束を容易に分離できないが，声带䩳帯に近 い部分では，全長 $2 \mathrm{~cm}$ の杵柬を分離できたといら．声 㴖勒带への筋束の附青を認めない。この状態は，横隔膜 の筋束汇比較できるという.

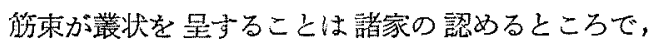
Goerttler pehringer \& M.thyreo-vocalis $と \mathrm{M}$. ary-vocelis の間の交織を述べている。

Mayet は, Portio thyreo-muscularis (Wustrow の分類を採用)は，声带唇の中 $1 / 3$ の部までの前部は声

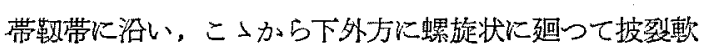
骨筋突起へつく．筇束の収縮によつて，この螺旋状は直 線に近くなるといつている。

私の所見では，声带靶帯に対し，前方より甲状声带突 起部と，後下゙方より甲状棈円简部の筋束がそれぞれゆる い弧を描いて向い互に交織しているが，声率鞂带に接し てはこれに平行に走つて，こ机に附着する筋束をみな い. 更に不定の筋束であるが勒帯の後方 $1 / 3$, 声声帯突 起附近で歎率に附着する披裂敬带部がある。

Shimert のいう極く短い筋束の連絡主る所見は得れ れずまた Wstrow のように Port. thyreo-vocalis, Portio thyreo-muscularis の, はつきりした二層に区別 されこれが披裂軟骨の位四によつて全く平行になると いら所見にも賛成できない。

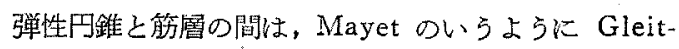
r aum があり，声帯唇の上面も同㺌で，筋束が嘧接して いるのは声帯鞄帯においてら゙ある.

今，搌頭各筋が収緶するとさは披裂軟骨が正中心よつ て両声带唇が相智るが，声帯唇自身の形態は，甲状披裂 解外側部の緊張が側方より加かり，下方より側輪状披裂 筋の毉㖘がこ机を支劣るから，声帯展は内方膨隆す る・同時に声帯筋束の緊張は, 声带唇を上下の方向に薄
くし，したがつて声帯野帯は更に内方に笑出して左右が 密着する・輪状甲状筋はこの密着の度を更に高めること になるのである。

声帯勒带に附着する披腊声帯部の存在する場合が、な いときにくらべて，特にどのような違いがあるが、不 明であるが，弾性円錐に附宦する筋束と同様に，声帯唇 緊張に役立つものとして認めたい。

\section{VI. 結 言}

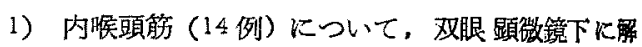
剖し，その配列，走向を検討した・別に組識連辡切片 (5 例）を作製し，これと比較した。筋走向を立体的你把握 する方法としては前者が後者に镸ると考觉る。

2）甲状四角膜筋（M. thyreo-memb.)，甲状搌頭盖 筋 (M. thyreo-epiglott.) ほ，小披裂四角膜筋 (M. ary. memb. min.) 小披裂脆頭蓋筇 (M. ary-epiglott. $\min$ ) と，喉頭室外側後部で交刃し，この部を作用点として，

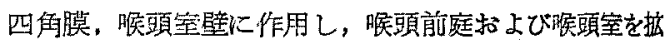
大する。

3）声帯筋は，甲状声帯突起部 (Pars thyreo-vocalis）甲状棈円䔰部 (Pars thyreo-oblongata) の二つの 部分に区別することができる・これらはいられる声带警 帯に附着しない.声帯勒帯後 $1 / 3$, 声带乫起附近沙附着 する筋束，披裂勒帯部 (Pars ary-ligamentosa)を14 例中 4 例に磪認した・

M. thyreo-vocalis (Goerttler) は磪認することがで きなかつた・

4）声帯唇に含まれる筇束の太さは，声帯䩲带に近く なるにしたがつて細くなる・靶帯に接する部分では，更 に細分して数本の觔線維程度になり，弾性線維間を，こ

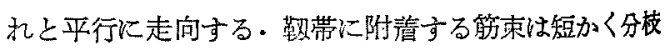
して、打の招の賿原線維に連なつて終つている.

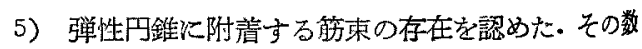
量には個体差があり，これを欠く例もあつた。

6)側輪状披裂筋，輪状甲状崭，披裂筋，後输状披裂 筇拉よび甲状披裂筋の作用について考察した・

7) 粘膜下結合組織注筋束と，声帯靶帯およひ仮声带

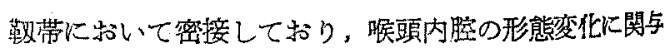
する。

8）胎生後期の院頭筋配列は，成人之ほ心゙咸じである。

$$
\text { 文献 }
$$

1) Ranke, O.F.u. Lullies, H: Lehrbuch der Physiologie: Gohör, Stimme u. Sprach. Springer. (1953). 2) Pressman, J. and Keleman, G: Phy- 
siology of the Larynx. Physiol. Review. 35; No.3,

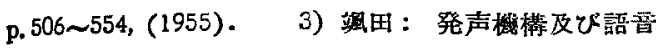

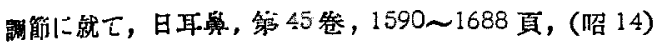
(1939). 4) 切替：喉頭ストロボ活動写真撮影法に よる発声時における人間声琶の振動並に゙声門開閉の時

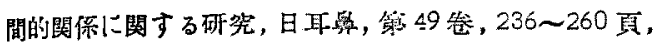

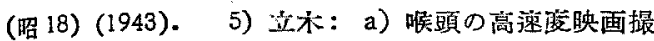

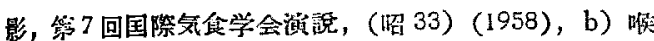
嘼梌柦法, (炤31) (1956). 6) Husson, R: Physi-

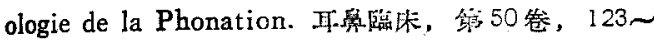
139 頁, (昭 32) (1957)。 7) Portmann G: The Physiology of Phonation. The Semon Lecture 1956. The Journal of Laryngology and Otology. P. 1 15. Jan. (1957). $\quad$ 8) Schumacher, S: Histologie der Luftwege und der Mudhöhle. A. Denker u. o. Kahler Handbuch der Hals, Nasen und Ohrenheilkude, Bd. I. S. 277 424, (Histologie des Kehlkopfes s. 376 399) Berlin u. München (1925).

9) Sieglbauer, F: Lehrbuch der normalen Anatomie des Menschen Berlin u. Wien Urban \& Schwarzenberg. (1935).

10) Rauber, Kopsch:

Lehrbuch und Atlas der Anatomie des Menschen. (1927). 11) Katzenstein, J: Über die elastischen Fasern in Kehlkopfe mit besonderer Berücksichtigung der Funktionellen Struktur und der Funktion der Wahren und falschen Stimmlippe. Arch. für Laryngologie. Bd. 13. S. 329 352 (1903). 12) Elze, C: Anatomie des Kehlkopfes und des Tracheobronchialbaumes. A. Denker u. O. Kahler Handbuch der Hals, Nasen u. Ohrenheilkunde Bd.I. S. 225 277. Berlin u. München (1925).

13) Fränkel, B: Zur Histologie der Stimmbänder. Virchows Arch. Bd. 118. S. 370 381 (1889). 14) Mayet, $A$; a) Bau u. Funktion des M. Vocalis u. Seine Beziehungen zu Lig. Vocale u. Conus elasticus. Acta anat. Bd. $2 \div$ S. $15 \sim 26$ (1955). b) Zur funktionellen Anatomie der menschlichen Stimmlippe. Zeitschr. für Anatomie und Entwicklungsgeschichte. Bd. 119 S. 87 111 (1955). 15) Lauthe, A: Neues Handbuch der pathologischen Anatomie Bd I. S. $473 \sim$ Wien, Stuttgart, Leipzig (1835). It) Henle. J: Vergleichende anatomische Betrachtungen des Kehlkopfes. Leip- zig (1839). Handbuch der Anatomie Bd. 2 (Eingew eidelehre) S. 246 256. (1866). 17) Ludwig. C: Lehrbuch der Physiologie des Menschen BdI. S. 567 570. Leipzig u. Heidelberg (1858). Jacobson, A.: Zur Lehre u. vom Bau u. der Funktion des M. Thyreoarytaenoideus beim Mens. chen. Arch. Mikrosk. Anat. Bd. 29. S. 617 629 (1887). 19) Luschka, H.V.. a) Kehlkopf des Menschen Tübingen: Laupp. (1871). b) Anatomie des Menschen (Hals) Tübingen (1862). 20) Verson, E.: Beiträge zur Kenntnis des Keh. lkopfes und der Trachea. Sitzgsber. Akad. Wiss. Wien, Math.-naturwiss. K L. III, Ma, 57. (1868). 21) Némai, J: Zur Anatomie u. Physiologie des Stimmorgans. Monatschr. f. Ohrenheikunde u. Laryngo.Rhinologie Bd. 71 S. $671 \sim 680$ (1937). 22) Goertller, K: Die Anordnung, Histologie und Histogenese der quergestreiften Muskulatur in menschlichen Stimmband. Zeitschr. für Anatomie und Entwicklungsgeschichte Bd. 115. S. 352 401. (1950). 23) Pernkopf, E: Topographische An. atomie des Menschen BdIII. S. 313

Trendelenburg, $W:$ Nenere Ergebnisse der Stimmphysiologie. Wien u. Berlin (1950). 25) Wu. strow, F: Bau u. Funktion des menschlichen Musculus Vocalis. Zeitschr. f. Anatomie u. Entwicklungegeschichte Bd. 116 S. $506 \sim 522$ (1952). 26) J.v.d. Berg u. Moll, J.: Zur Anatomie des menschlichen Musculus Vocalis. Zeitschr. f. Anatomie u. Entwicklungsgeschichte Bd. 118 S. 465 〜70 (1955). 27) Schlosshauer, B.u. Vosteen, K.H.: a) Über den Verlauf u. die Funktion der Stimmuskelfasern. Zeitschr. f. Anatomie u. Ent. wicklungsgeschichte. Bd. 120 S. 456 465 (1958).

b) Über die Anordnung u. Wirkungsweise der in Conus elasticus ansetzenden Fasern des Stimmuskels. Zeitschr, Laryngologie u. Rhinologie Bd. 36. S. 642 650 (1957). 28) Behringer, S: Die Anordnung der Muskulatur in der menschlichen Stimmlippe und im Gebiet des Conus elasticus. Zeitshr. f. Anatomie u. Entwicklungschichte. Bd 118. S. 324 342 (1955). 29) Nihonsugi, K.: On the Laryngeal Musculature of the Japanese. 
Acta Scholae Med. Univ. Imp. Kioto. p. $75 \sim 122$ (1922). 30) Kano, S: Beiträge zur Lehre von feineren Bau des Kehlkopfes. Zeitschr. f. Ohrenheilkunde u. für die Krankheinten der Luftwege. Bd. 61 S. 121 146 (1910). 31) 小西，小山1：胎

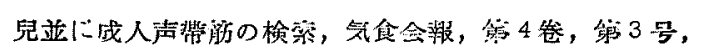
(炤28) (1953). 32) Oishi, K: Observations on the Laryngeal Muscles of Madam Tamaki Miura, Primadonna of the "Madam Butterfly" Okajimas Folia Anatomica Japonica Vol. 28. p. 581 594

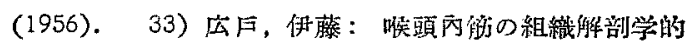

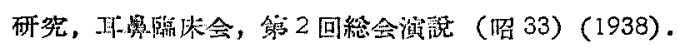
34) Stroud, M.H. and Zwiefa:h, E: Mechanism of the Larynx and Recurrent Nerve Palsy. Jonrnal of Laryngology p. 86 96 Vol. 70 (1956). Capps, H.C.W: "Abductor Paralysis" in Theory and Practice since Semon. Journal of Laryngology Vol. 72 p.1 31 1958. 36) Shimert, J: Über den feineren Bau einigen Muskeln des Menschen mit besonderer Berücksichtigung der Länge u. Anordnung der guergestreiften Musklfasern. Zeitschr. f. mikr. anat. Forsheung Bd. 36. S. $215 \sim 230$ (1934).

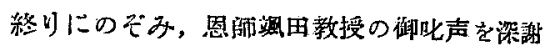
し，実験の御指朗，御校閱を睗わつた切替教授 ならびに大石助教授に感謝の意を装する。

なお，本材料を提供された東京都監察医狋院 および村料の提供，租織作製の缏宜を与えられ

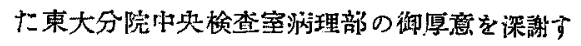
る.

本論文の一部は，日本耳悬喵喉科学会第 57 回総会 (妿 31 年) 於よび音声言語医学会第三回 （昭33 年）に笔㠇した。

（原稿到着=炤和 34.6.24 日一急载） 


\section{万城目論 文 付図 (I)}

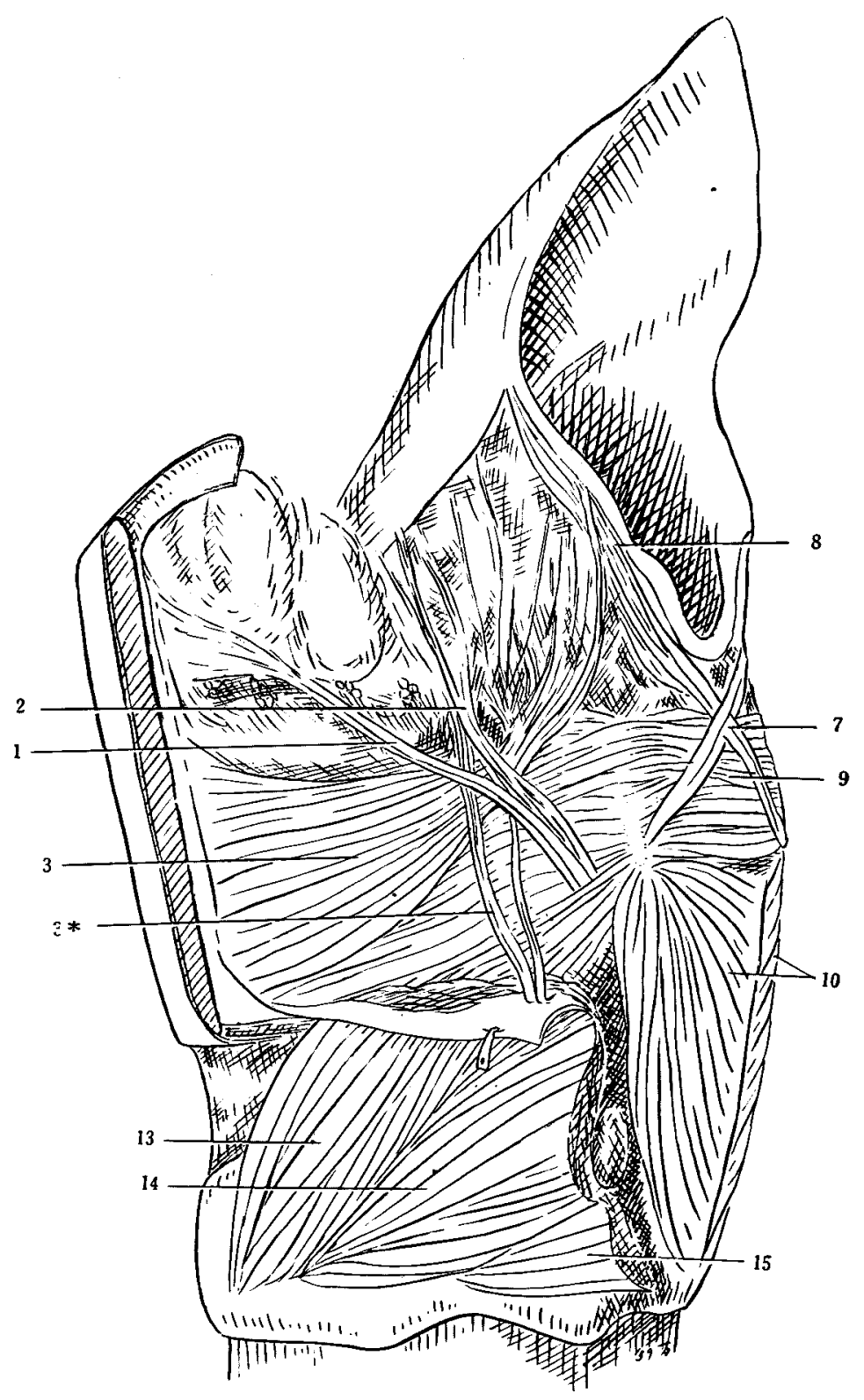

第 1 图 a. 47 才

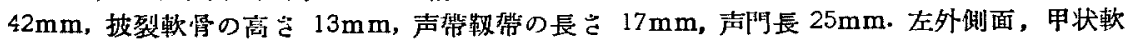
骨板ちよび四过頭喉頭蓋節を除く・

(1) M. thyreo aryt. sup. (2) M. ary-epiglott. min., M. ary-memb. min. (3) M. thyreoepiglott., M. thyreo-memb. (3)* 下本状結㓩におこる節束 (7) M. aryt. obliq. (8) M. aryepiglott. maj. (9) M. aryt. trans. (10) M. crico-aryt. post. (13) M. crico- thyreoid. Pars rect. (14) M. crico-thyreoid. Pars obliq. (15) M. crico-pharyng. 
万城目論交付図 (II)

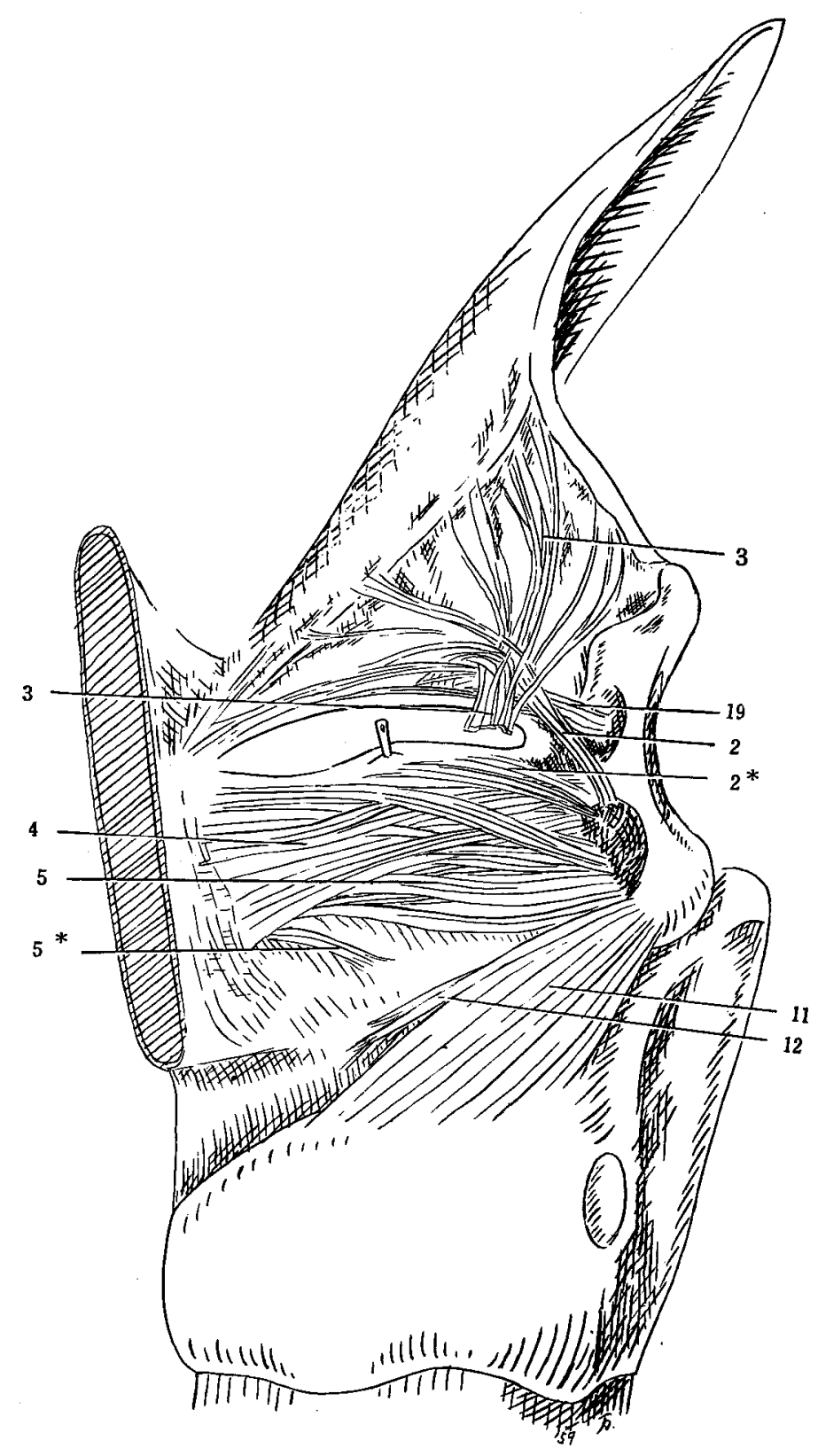

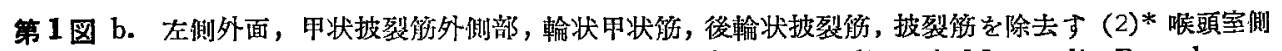
壁に停止する筋束 (4). M. vocalis, Pars, thyreo-vocalis (5) M. vocalis, Pars thyreooblongata (5)* 彈性四錐に停止する筋柬. 本例では太く明暸である (11) M. crico-aryt. lat. (12) M. syndesmo-aryt. (19) M. ventricul. 
万城目論文付図 (III)

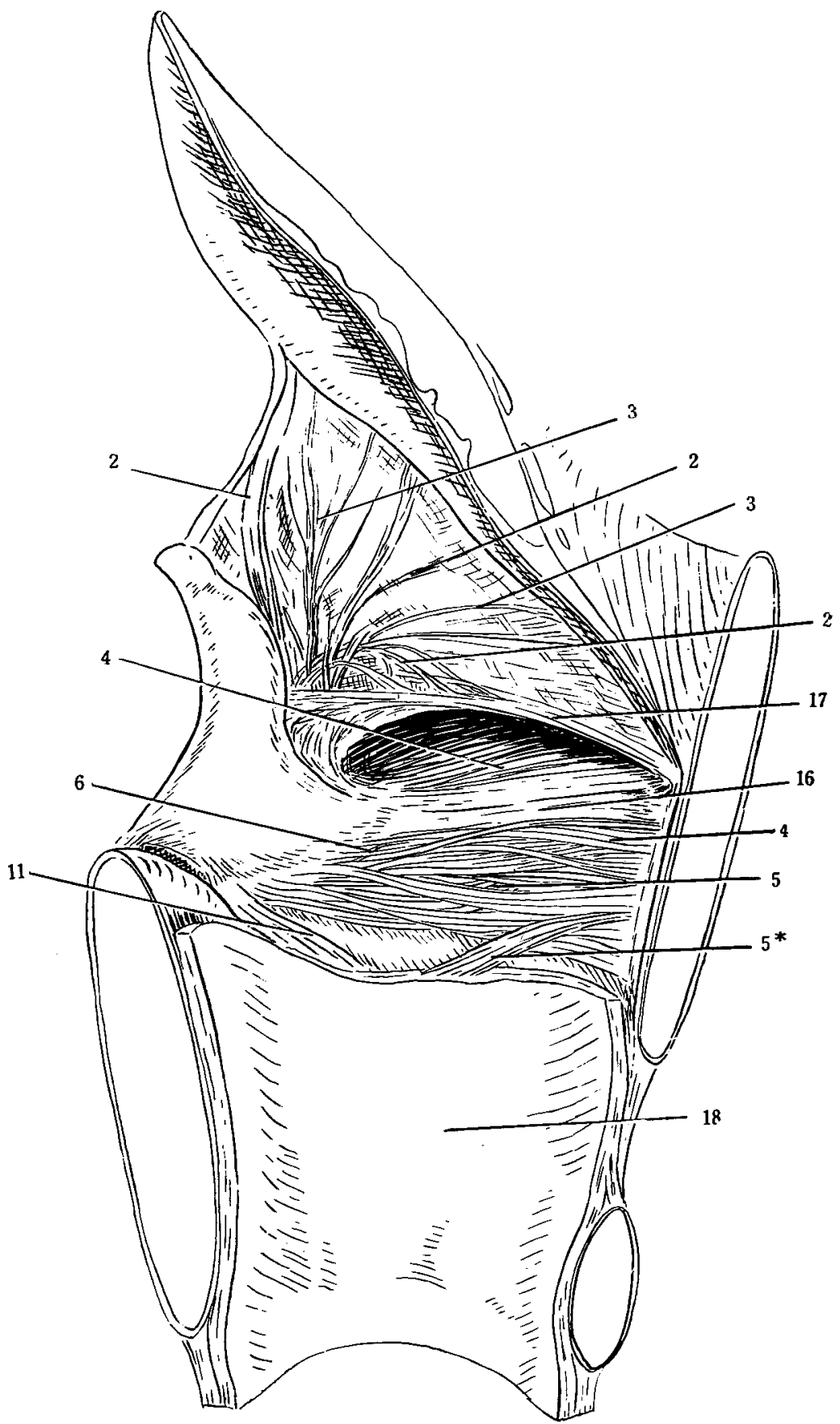

第 1 图 c. 左側內面，粘膜を除去す (6) M. vocalis, Pars ary-ligamentosa (16) Liq. vocale (17) Liq. ventriculare (18) Conus. elast. (5)* 彈性四錐に停止する籍束 


\section{万城 目 論 文 付 図 (V)}

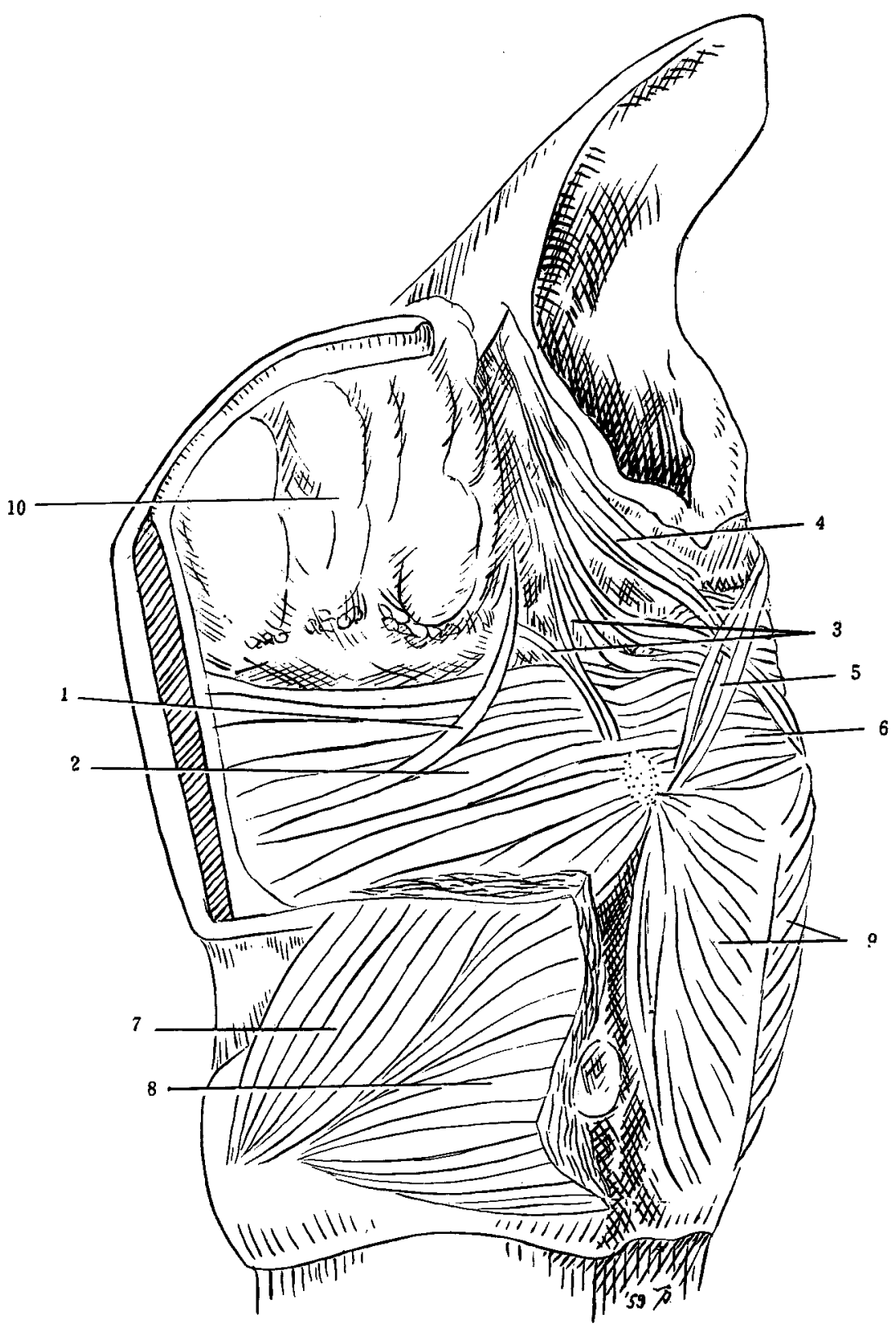

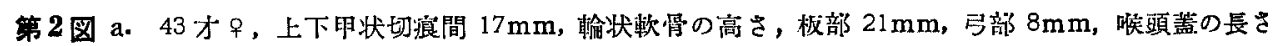

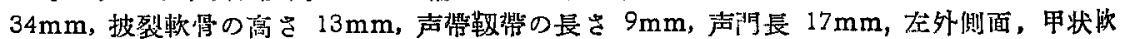

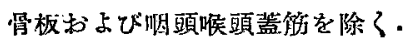

(1) M. thyreo-epiglott., M. thyreo-memb. (2) M. thyreo-arytenoid. ext. (3) M. ary-epiglott. min., M. ary-memb. min. (4) M. ary-epiglott. maj. (5) M. aryt. oblig. (6) M. aryt. trans. (7) M. crico-thyreoid. Pars rect. (8) M. crico-thyreoid. Pars obliq. (9) M. crico-aryt. post. (10) Corp. adipos. 


\section{万城目論文付図 ( $\boldsymbol{V})$}
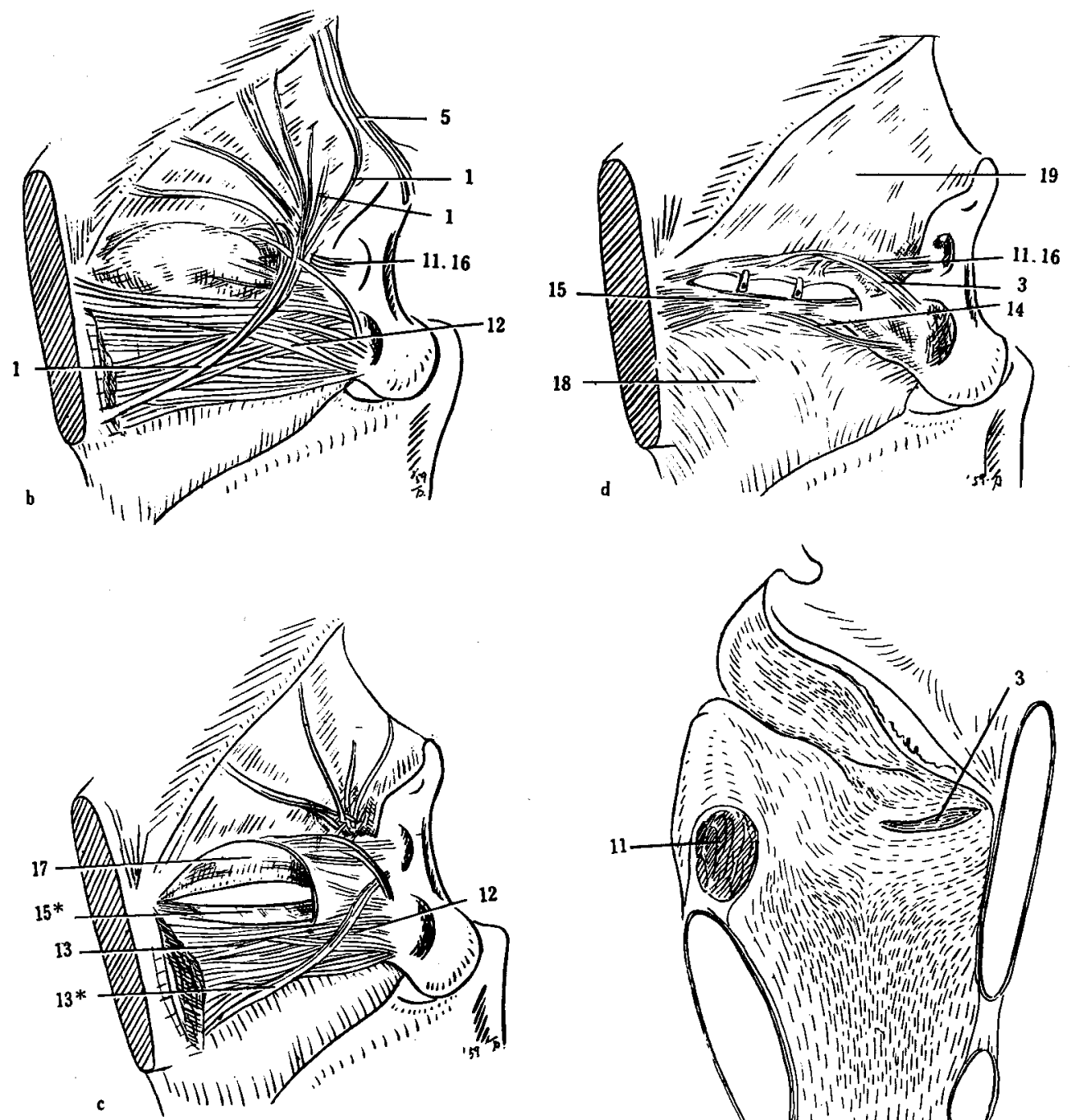

第 2 図 b. c. d. 㮌に丙層の颌束を示す (11). M. ventricul. (12) M. vocalis, Pars thyreooblongata (13) M. vocalis, Pars thyreo-vocalis

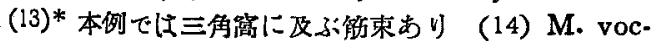
alis, Pars ary-ligamentosa (15) Lig. vocale (15)* 声替唇粘膜 (16) Lig. ventriculare (17) 喉頭室內 壁 (18) Conus elast. (19) Memb. quadrangul.

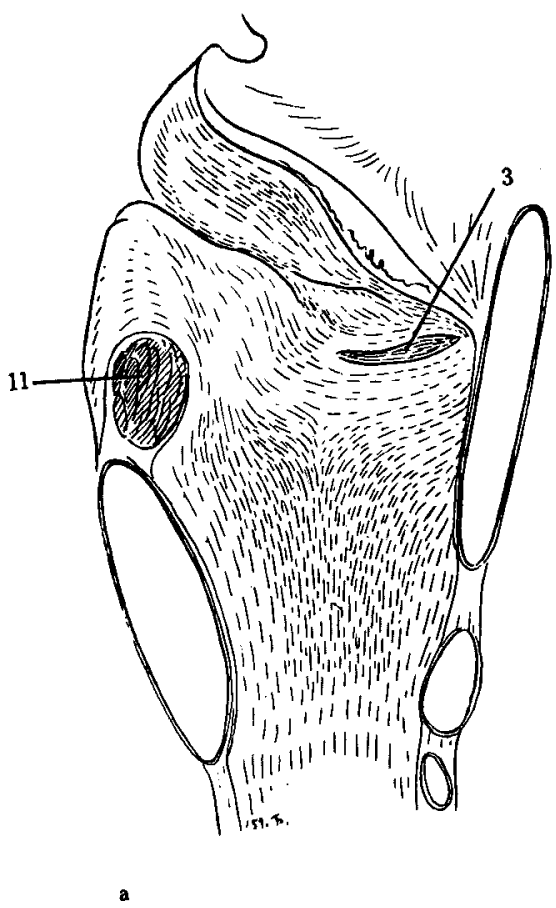

第 3 図 a. 粘膜の裂隙線

7 ケ月の胎兒 (体長 $36 \mathrm{~cm}$, 体重 $610 \mathrm{gr}$ ) 。 . 上下甲 状切痕間 $5 \mathrm{~mm}$, 輸状軟骨の高さ, 板部 $6 \mathrm{~mm}$, 弓部 $2 \mathrm{~mm}$, 喉頭蓋の長さ $9 \mathrm{~mm}$, 披裂軟骨高さ $4 \mathrm{~mm}$, 声 帶䩲帶の長さ $1 \mathrm{~mm}$, 声!坷長 $4.5 \mathrm{~mm}$.

(3) Ventr. laryngis (11) M. aryt 
万城 目論 交 付図 (II)
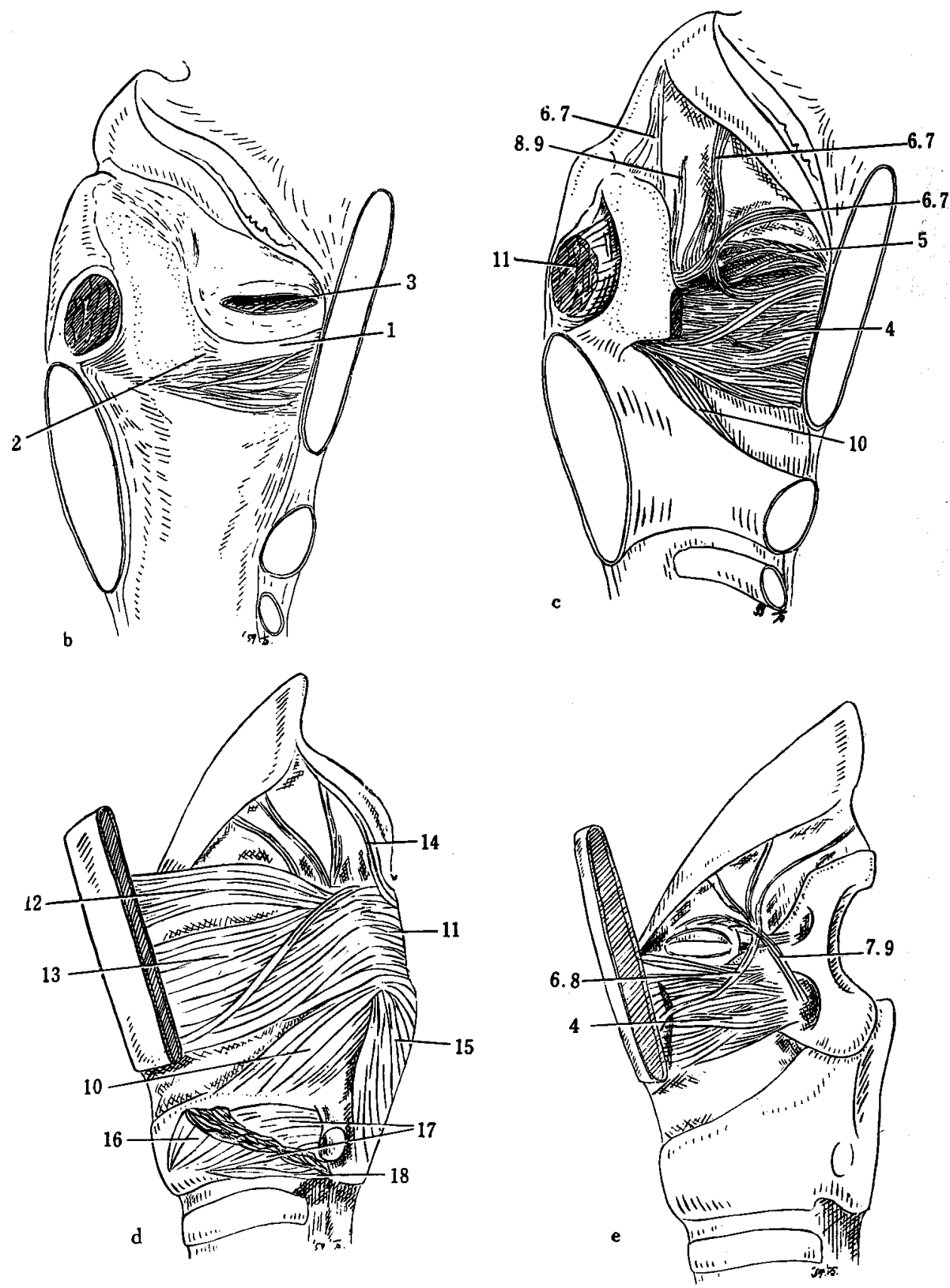

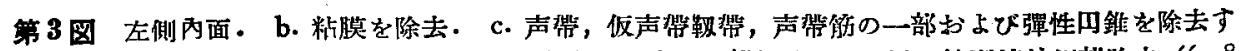

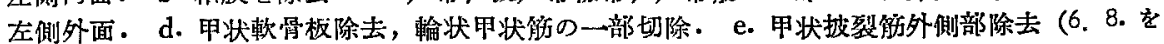

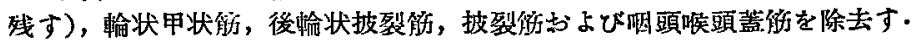

(1) Lig. vocale (2) Proc. vocalis. (3) Ventr. laryngis (4) M. vocalis, Pars thyreo-oblongata (5) M. ventriculare (6) M. thyreo-epiglott. (7) M. ary-epiglott. min. (8) M. thyreo-memb. (9) M. ary-memb. min. (10) M. crico-aryt. lat. (11) M. aryt. trans. (12) M. thyreo-aryt. sup. (13) M. thyreo-aryt. ext. (14) M. ary-epiglott. maj. (15) M. crico-aryt. post. (16) M. crico-thyreoid. Pars rect. (17) M. crico-thyreoid. Pars obliq. (18) M. crico-pharyng. 


\section{万城目論文付図 (VII)}

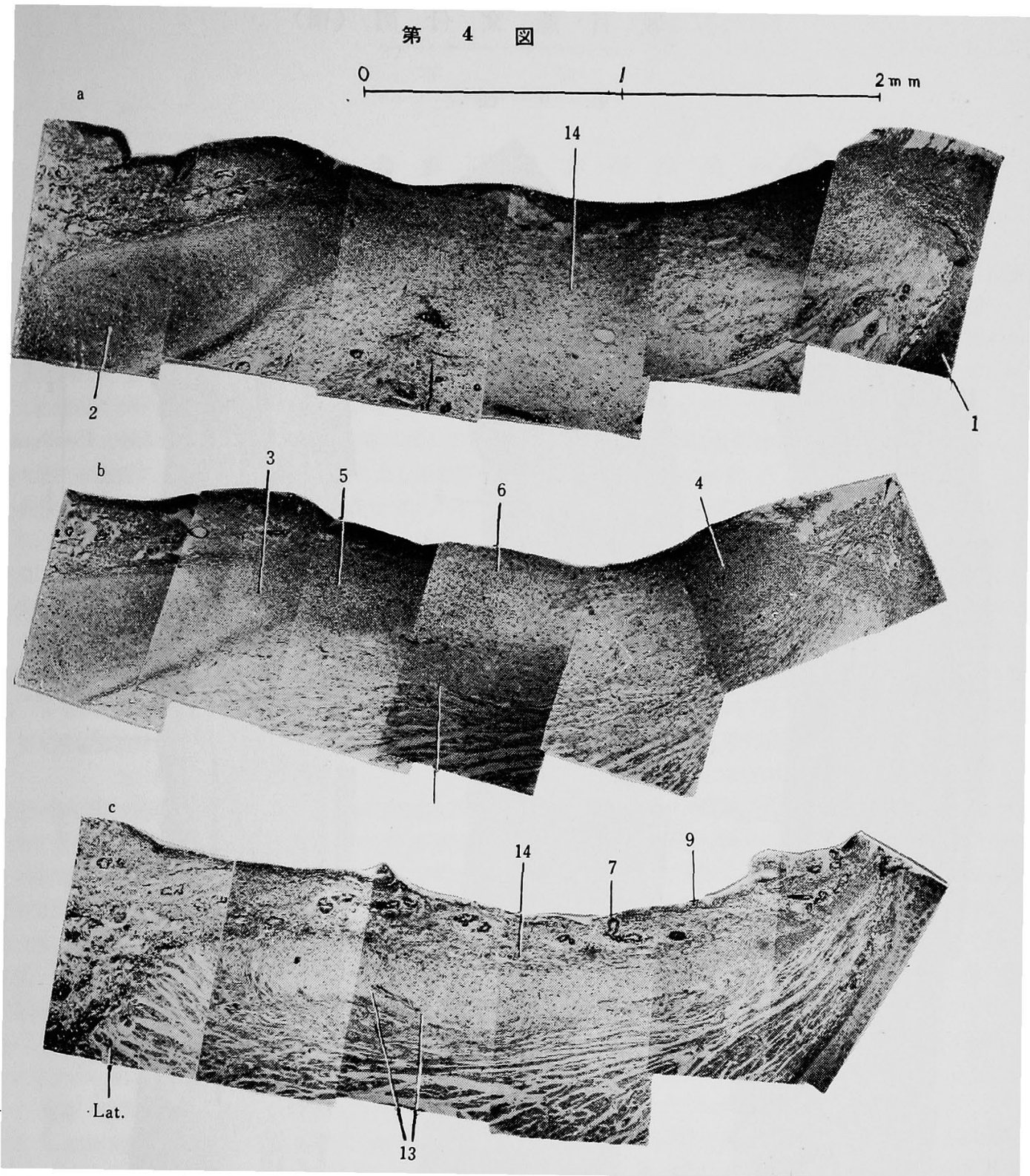

第4図 6 力月胎兒乃右, 水平断

厚さ $6 \mu$ × ェスチカ,ワンギーソン染色
第 5 図 30才? 左, 水平断

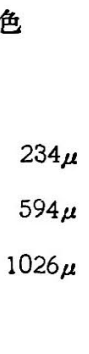

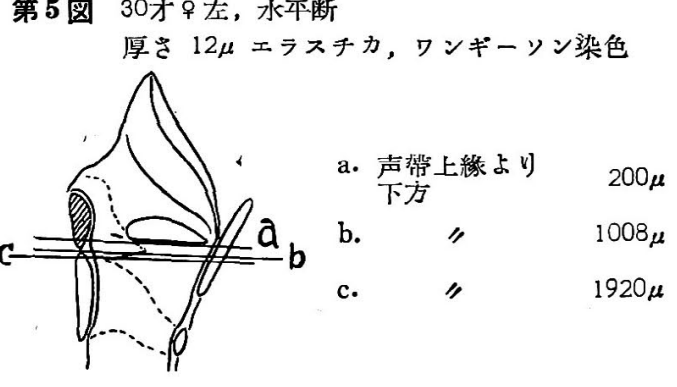

(1) Cartilago thyreoidea (2) Cartilago arytenoidea (3) Proc. vocalis (4) Macula flava ant, (5) Macula flava post. (6) Lig. vocale (7) Gl. laryngeae (8) Plattenepithel (9) Flimmerepithel (10) 筋束の附着とみえるが決定はしつかしい. 膠原線維が結線維端に゙ついて一見終るようにも

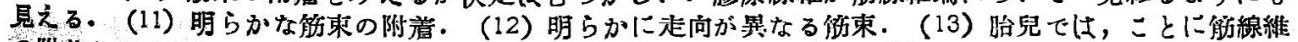
附差を決的がたい.（14）膠原線維が多く彈性線維が少ない. (Lat) M. crico-aryt. lat. 


\section{万城目論交付図 (VIII) \\ 第一两}

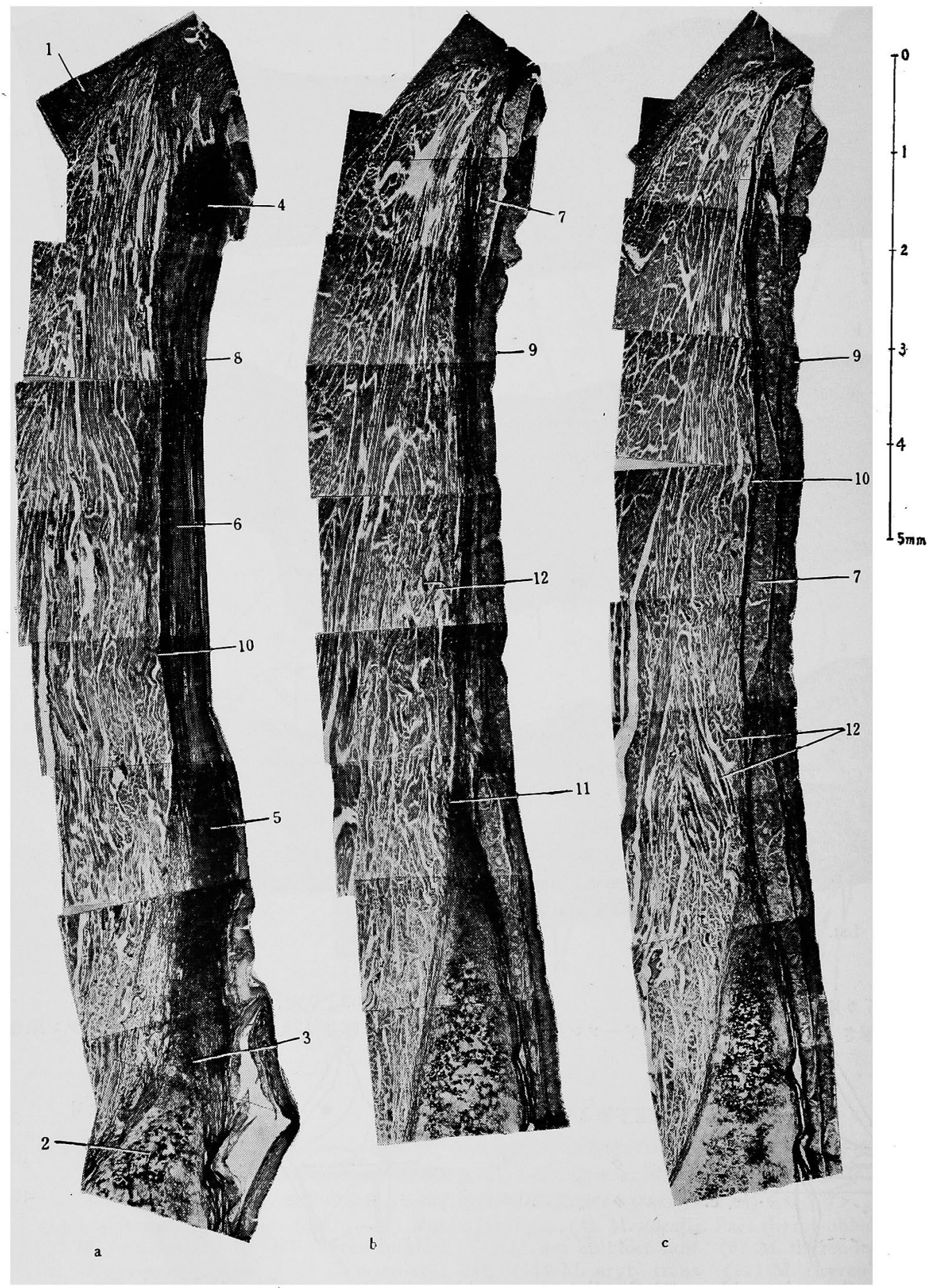

